\title{
Estimating the climate significance of halogen-driven ozone loss in the tropical marine troposphere
}

\author{
A. Saiz-Lopez ${ }^{1}$, J.-F. Lamarque ${ }^{2}$, D. E. Kinnison ${ }^{2}$, S. Tilmes ${ }^{2}$, C. Ordóñez ${ }^{1}$, J. J. Orlando ${ }^{2}$, A. J. Conley ${ }^{2}$, \\ J. M. C. Plane ${ }^{3}$, A. S. Mahajan ${ }^{1}$, G. Sousa Santos ${ }^{4}$, E. L. Atlas ${ }^{5}$, D. R. Blake ${ }^{6}$, S. P. Sander ${ }^{7}$, S. Schauffler ${ }^{8}$, \\ A. M. Thompson ${ }^{9}$, and G. Brasseur ${ }^{10}$ \\ ${ }^{1}$ Laboratory for Atmospheric and Climate Science, CSIC, Toledo, Spain \\ ${ }^{2}$ Atmospheric Chemistry Division, NCAR, Boulder, CO, USA \\ ${ }^{3}$ School of Chemistry, University of Leeds, Leeds, UK \\ ${ }^{4}$ Institute for Atmospheric and Climate Science, ETH, Zurich, Switzerland \\ ${ }^{5}$ Rosenstiel School of Marine and Atmospheric Science, University of Miami, Miami, FL, USA \\ ${ }^{6}$ Department of Chemistry, University of California, Irvine, CA, USA \\ ${ }^{7}$ Jet Propulsion Laboratory, California Institute of Technology, CA, USA \\ ${ }^{8}$ Earth Observing Laboratory, NCAR, Boulder, CO, USA \\ ${ }^{9}$ Department of Meteorology, Pennsylvania State University, Pennsylvania, USA \\ ${ }^{10}$ Climate Service Center, Hamburg, Germany
}

Correspondence to: A. Saiz-Lopez (a.saiz-lopez@ciac.jccm-csic.es)

Received: 2 September 2011 - Published in Atmos. Chem. Phys. Discuss.: 6 December 2011

Revised: 1 March 2012 - Accepted: 12 April 2012 - Published: 4 May 2012

\begin{abstract}
We have integrated observations of tropospheric ozone, very short-lived (VSL) halocarbons and reactive iodine and bromine species from a wide variety of tropical data sources with the global CAM-Chem chemistry-climate model and offline radiative transfer calculations to compute the contribution of halogen chemistry to ozone loss and associated radiative impact in the tropical marine troposphere. The inclusion of tropospheric halogen chemistry in CAM-Chem leads to an annually averaged depletion of around $10 \%(\sim 2.5$ Dobson units) of the tropical tropospheric ozone column, with largest effects in the middle to upper troposphere. This depletion contributes approximately $-0.10 \mathrm{~W} \mathrm{~m}^{-2}$ to the radiative flux at the tropical tropopause. This negative flux is of similar magnitude to the $\sim 0.33 \mathrm{~W} \mathrm{~m}^{-2}$ contribution of tropospheric ozone to presentday radiative balance as recently estimated from satellite observations. We find that the implementation of oceanic halogen sources and chemistry in climate models is an important component of the natural background ozone budget and we suggest that it needs to be considered when estimating both preindustrial ozone baseline levels and long term changes in tropospheric ozone.
\end{abstract}

\section{Introduction}

Tropospheric ozone $\left(\mathrm{O}_{3}\right)$ is one of the most important shortlived gases contributing to greenhouse radiative forcing (RF) (Forster et al., 2007). It is produced by photochemical oxidation of carbon monoxide $(\mathrm{CO})$, methane $\left(\mathrm{CH}_{4}\right)$ and nonmethane volatile organic compounds (NMVOC) in the presence of nitrogen oxides $\left(\mathrm{NO}_{\mathrm{x}}\right)$. A large fraction of the tropospheric ozone loss occurs within the tropical marine boundary layer (TMBL) via photolysis to excited oxygen atoms $\mathrm{O}\left({ }^{1} \mathrm{D}\right)$, followed by reaction with water vapour, reactions with odd hydrogen radicals $\left(\mathrm{HO}_{\mathrm{x}}\right)$, and surface deposition (Horowitz et al., 2003). However, since conventional $\mathrm{HO}_{\mathrm{x}}$ chemistry and ozone photochemistry cannot account for the observed ozone variability in the TMBL, it has been suggested that reactive halogen species released into the atmosphere by the photodecomposition of organohalogens and via autocatalytic recycling on sea-salt aerosols may also contribute to ozone destruction in this environment (e.g. Dickerson et al., 1999; Read et al., 2008).

Measurements of low ozone levels ( $<10 \mathrm{ppbv})$ and large diurnal variability of surface ozone have been reported over 
the tropical regions of the Atlantic Ocean (Oltmans and Levy II, 1992; Dickerson et al., 1999), Pacific Ocean (Johnson et al., 1990; Kley et al., 1996; Nagao et al., 1999; Shiotani et al., 2002; Takashima et al., 2008), and Indian Ocean (Johnson et al., 1990; Bremaud et al., 1998; Dickerson et al., 1999; de Laat et al., 1999; Burket et al., 2003). Tropical ozonesonde data also show events of substantially reduced ozone levels in the upper troposphere at different locations throughout the tropics (Solomon et al., 2005), although Vömel and Diaz (2010) claim that such events might be caused by artefacts in the measurement procedures. Despite the considerable number of low ozone events reported, only recently has halogen-induced ozone destruction been unambiguously demonstrated over the tropical oceans (Read et al., 2008).

The reduction in tropospheric ozone due to bromine chemistry has been previously studied with 3-dimensional global chemistry transport models (CTMs) (von Glasow et al., 2004; Yang et al., 2005), but those studies did not include the combined effect of bromine and iodine sources. Moreover, the resulting radiative impact of halogen-driven ozone loss in the tropical marine troposphere has not been quantified so far. In this study we integrate observations of tropospheric ozone, very short-lived (VSL) halocarbons - halogenated organic compounds with atmospheric lifetimes of less than 6 months (WMO, 2011), and reactive iodine and bromine species from a wide variety of tropical data sources with the global CAM-Chem chemistry-climate model and radiative transfer calculations to estimate the impact of halogen chemistry on ozone loss and radiative balance in the tropical marine troposphere.

\section{Description of the chemistry-climate model}

CAM-Chem is the global three-dimensional Community Atmosphere Model (CAM) (Gent et al., 2010), modified to include interactive chemistry (i.e. with feedback to the radiation calculation in the atmosphere) and calculate distributions of gases and aerosols (Lamarque et al., 2012). Here we use CAM-Chem with a horizontal resolution of $1.9^{\circ}$ (latitude) $\times 2.5^{\circ}$ (longitude) and 26 hybrid vertical levels from the surface to approximately $40 \mathrm{~km}$, with a model timestep of $30 \mathrm{~min}$. The model has a full representation of tropospheric (Emmons et al., 2010) and stratospheric (Kinnison et al., 2007) chemistry. CAM-Chem has been used here with the same configuration as in a variety of applications with a focus both on the troposphere (e.g. Lamarque et al., 2010) and the lower stratosphere (e.g. Lamarque and Solomon, 2010). Details on the bulk aerosol parameterizations are given elsewhere (e.g. Lamarque et al., 2012; Ordóñez et al., 2012).

The scope of CAM-Chem has been extended to include natural sources of VSL halocarbons from the ocean; reactive chlorine, bromine and iodine species; related photochemical, gas-phase and heterogeneous reactions, as well as dry and wet deposition for relevant species. A detailed description of the new halogen sources and chemistry scheme implemented in CAM-Chem can be found in the companion paper (Ordóñez et al., 2012). Briefly, the tropospheric halogen chemical scheme follows that of the 1-dimensional Tropospheric HAlogen chemistry MOdel (THAMO) (Saiz-Lopez et al., 2008), which has recently been used to model reactive halogen species over the tropical Atlantic Ocean (Mahajan et al., 2010). To determine the emissions of VSL bromocarbons $\left(\mathrm{CHBr}_{3}, \mathrm{CH}_{2} \mathrm{Br}_{2}, \mathrm{CH}_{2} \mathrm{BrCl}, \mathrm{CHBr} 2 \mathrm{Cl}\right.$, and $\left.\mathrm{CHBrCl}_{2}\right)$ and iodocarbons $\left(\mathrm{CH}_{2} \mathrm{I}_{2}, \mathrm{CH}_{2} \mathrm{IBr}\right.$ and $\left.\mathrm{CH}_{2} \mathrm{ICl}\right)$, Ordóñez et al. (2012) used a compilation of aircraft campaigns and some observations available in the marine boundary layer. Over the tropical oceans $\left(20^{\circ} \mathrm{S}-20^{\circ} \mathrm{N}\right)$ these emission fields follow the geographical distribution of the Phytoplankton Pigment Concentration (PPC) retrieved from SeaWIFS satellite data, while they consist of constant oceanic fluxes with a fixed 2.5 coast to ocean emission ratio in the extratropics (Sousa Santos, 2008; Ordóñez et al., 2012). Unlike in Ordóñez et al. (2012), the emission sources used for this study have only been extended to the mid-latitude oceans (up to $50^{\circ}$ in both hemispheres). Emissions for methyl iodide $\left(\mathrm{CH}_{3} \mathrm{I}\right)$ are based on the inventory from a previous modelling study (Bell et al., 2002), while the longer-lived methyl bromide $\left(\mathrm{CH}_{3} \mathrm{Br}\right)$ concentration is set as a lower boundary condition (see below). We assume that the emission of all VSL halocarbons is photosynthetically driven and depends on the actinic flux, with a diurnal variation described by a Gaussian profile peaking at noon and null at night. There is no clear evidence on the dependence of the sea-air emission of VSL halocarbons on the actinic flux. While the surface water concentrations of these species may decay with light (e.g. Hense and Quack, 2009), other analyses (e.g. Reeser et al., 2009) suggest that at least some organohalides could arise from photochemical processes in salt-water solutions containing chlorophyll. Our approach brings the model's predictions for these species in reasonable agreement with observations as shown by Ordóñez et al. (2012), who also discussed the limitations of the emission parameterisation used here.

Sea-salt is also an important source of reactive halogens in the troposphere. The heterogeneous recycling of halogens on sea-salt aerosols is treated as follows in CAM-Chem. The uptake and subsequent hydrolysis of $\mathrm{XONO}_{2}, \mathrm{HOX}$ and $\mathrm{XNO}_{2}$ $(\mathrm{X}=\mathrm{Cl}, \mathrm{Br}$ or I) on marine aerosols produces $\mathrm{HOX}$, which equilibrates between the gas and aqueous phases according to its Henry's law solubility. We do not explicitly treat the aqueous phase chemistry in the bulk of the sea-salt aerosols. Instead, we assume that the rate-limiting step of the process is the uptake of inorganic halogen species onto aerosols, which is computed using the free molecular transfer regime approximation (McFiggans et al., 2000). Then aqueous HOX is processed to $\mathrm{Br}_{2}, \mathrm{BrCl}, \mathrm{IBr}, \mathrm{ICl}$ and $\mathrm{Cl}_{2}$ via reaction with $\mathrm{Br}^{-}$, $\mathrm{Cl}^{-}$and $\mathrm{I}^{-}$on sea-salt aerosols. The resulting di-halogen molecules are insoluble and therefore rapidly released to the gas phase. Further details can be found in the Supplement of Ordóñez et al. (2012). Due to their large size, sea-salt 
particles are quickly removed from the atmosphere by sedimentation and wet scavenging; this limits the relevance of this process to the marine boundary layer (MBL).

One-dimensional model analyses constrained with observed iodocarbon fluxes (Mahajan et al., 2010; Jones et al., 2010) suggest that a substantial source of iodine is required to support the observed iodine oxide (IO) levels over the tropical Atlantic Ocean. From observations at different coastal locations there is evidence that this additional source may be in the form of molecular iodine $\left(\mathrm{I}_{2}\right)$ (SaizLopez and Plane, 2004). Laboratory studies (Garland and Curtis, 1981; Sakamoto et al., 2009) have shown that deposition of $\mathrm{O}_{3}$ on the sea surface may lead to the emission of $I_{2}$. Similarly, there are reports on the photosensitised production of volatile halogen species at the sea surface (Reeser et al., 2009). Therefore, we use a flux of inorganic iodine (i.e. $\mathrm{I}_{2}$ ) along with the iodocarbon flux to reproduce the observed IO at the different tropical locations where IO has been observed at pptv levels (e.g. Eastern Pacific, Tropical Atlantic and Indian Ocean). In the simulation presented here, this is accounted for by a global total $\mathrm{I}_{2}$ emission field of $\sim 1200 \mathrm{Gg} \mathrm{yr}^{-1}$, with the same geographical distribution as that of the above mentioned VSL halocarbons but with no diurnal variation. The average $\mathrm{I}_{2}$ flux over the tropical oceans in CAM-Chem (including open oceans, upwelling regions and coastal areas within $20^{\circ} \mathrm{N}-$ $20^{\circ} \mathrm{S}$ ) is $4.9 \times 10^{7}$ molecule $\mathrm{cm}^{-2} \mathrm{~s}^{-1}$, very close to the constant day and night $\mathrm{I}_{2}$ flux of $5.0 \times 10^{7}$ molecule $\mathrm{cm}^{-2} \mathrm{~s}^{-1}$ considered in Mahajan et al. (2010) for the tropical Atlantic Ocean around Cape Verde. Note that the lifetime of $I_{2}$ is too short (i.e. seconds) to be transported to the mid-upper troposphere. As a consequence, the model results for that region of the atmosphere are not expected to be very sensitive to the $\mathrm{I}_{2}$ flux. However the emission of $\mathrm{I}_{2}$, subsequent photolysis and further halogen- $\mathrm{HO}_{\mathrm{x}}$-ozone reactions in the TMBL may have an impact on the amount of ozone transported to the mid- and upper troposphere.

At the lower boundary, the time-varying (monthly values) zonal-averaged distributions of $\mathrm{CO}_{2}, \mathrm{CH}_{4}, \mathrm{H}_{2}, \mathrm{~N}_{2} \mathrm{O}$, and long-lived halocarbons (CFC-11, CFC-12, CFC-113, HCFC22, $\mathrm{H}-1211, \mathrm{H}-1301, \mathrm{CCl}_{4}, \mathrm{CH}_{3} \mathrm{CCl}_{3}, \mathrm{CH}_{3} \mathrm{Cl}, \mathrm{CH}_{3} \mathrm{Br}$ ) are specified following their observed surface concentrations for 2000. Emissions from anthropogenic activities and biomass burning (natural and anthropogenically-forced) are equivalent to those from a MOZART-4 simulation for the year 2004 (Emmons et al., 2010).

Two 10-yr simulations of CAM-Chem, with and without VSL halocarbons, were conducted. For these model runs, climatological sea surface temperatures and sea-ice extent (Rayner et al., 2003) were set as lower boundary conditions. Hence CAM-Chem only solved for the atmospheric and land portions of the climate system, and the simulations do not pertain to any specific meteorological year. The model output shown here corresponds to the last year of those simula- tions. We only present results from the simulation with VSL halogenated species unless otherwise stated.

\section{Results of the chemistry-climate model}

\subsection{Halocarbons and halogen radicals}

Bromoform $\left(\mathrm{CHBr}_{3}\right)$ and $\mathrm{CH}_{3} \mathrm{I}$ are the main VSL halocarbons contributing to the total tropospheric bromine and iodine burden, respectively (WMO, 2011). Their tropospheric lifetimes are long enough - local lifetime (calculated using an average tropospheric $\mathrm{OH}$ concentration of $1 \times 10^{6}$ molecule $\mathrm{cm}^{-3}$ and the $\mathrm{OH}$ reaction rate constant at $T=275 \mathrm{~K}$ ) of $\sim 24$ days for $\mathrm{CHBr}_{3}$ and $\sim 7$ days for $\mathrm{CH}_{3} \mathrm{I}$ (WMO, 2011) - for them to be transported to the upper troposphere within deep convection areas. By contrast, emissions of other iodocarbons (e.g. $\mathrm{CH}_{2} \mathrm{ICl}, \mathrm{CH}_{2} \mathrm{IBr}$ and $\mathrm{CH}_{2} \mathrm{I}_{2}$ ), which have shorter lifetimes on the order of a few hours to minutes, and catalytic bromine release from seasalt aerosols provide a source of reactive halogens in the TMBL. The simulated vertical profiles of $\mathrm{CHBr}_{3}$ and $\mathrm{CH}_{3} \mathrm{I}$ in the tropical troposphere are in good agreement, both in magnitude and vertical distribution, with a composite of aircraft observations from three field campaigns: PEM-Tropics A (Hoell at al., 1999), PEM-Tropics B (Raper et al., 2001), and TRACE-P (Jacob et al., 2003) (Fig. 1). Two longer lived bromocarbons that additionally contribute to the tropospheric halogen burden have been examined: $\mathrm{CH}_{3} \mathrm{Br}$ (total lifetime of $\sim 0.8 \mathrm{yr}$ considering both photochemical loss in the atmosphere and uptake to oceans and soil) and $\mathrm{CH}_{2} \mathrm{Br}_{2}$ (local lifetime of $\sim 123$ days) (WMO, 2011). Their average modelled profiles throughout the tropical troposphere are also comparable to the observations (Fig. 1). The slight overestimation of $\mathrm{CH}_{3} \mathrm{Br}$ by the model for PEM-Tropics B (1999) and TRACE-P (2001) may be partly related to the decline in the industrial production of this compound since the mid/end of the 1990s (WMO, 2011). More details on the evaluation of $\mathrm{CH}_{3} \mathrm{Br}$ and VSL halocarbon species, including the shortest lived iodocarbons which are not shown here (i.e. $\mathrm{CH}_{2} \mathrm{ICl}$, $\mathrm{CH}_{2} \mathrm{IBr}$ and $\mathrm{CH}_{2} \mathrm{I}_{2}$ ), can be found in Ordóñez et al. (2012).

The reactive species bromine oxide $(\mathrm{BrO})$ and $\mathrm{IO}$ have been observed over the Atlantic, Indian and Pacific Oceans from a variety of measuring platforms. The computed daytime average boundary layer distribution of these species in the model lies within 0.5-2 pptv, in good accord with a compilation of reported observations in the tropical regions (Fig. 2). In the tropical upper troposphere there are only two studies from balloon-based platforms reporting observations of $\mathrm{BrO}$ and IO over Northern Brasil (Dorf et al., 2008; Butz et al., 2009). The simulated mixing ratios of $\mathrm{BrO}(\sim 0.5 \mathrm{pptv})$ and IO ( $\sim 0.02$ pptv) are below the $\sim 1$ pptv BrO (Dorf et al., 2008 ) and the upper limit of $\sim 0.2$ pptv IO (Butz et al., 2009) reported for that location in the upper troposphere. 

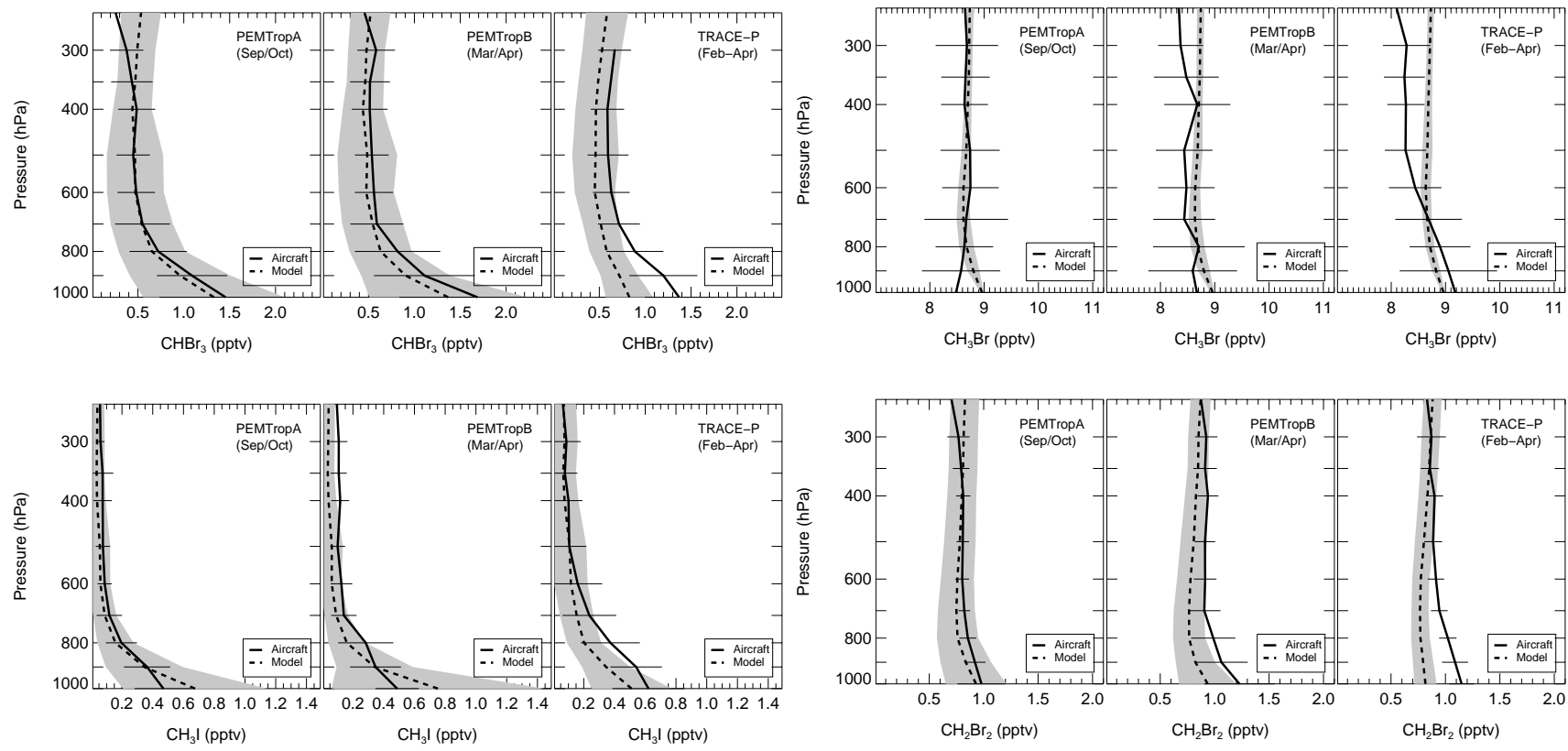

Fig. 1. Comparison of average vertical profiles of $\mathrm{CHBr}_{3}, \mathrm{CH}_{3} \mathrm{I}, \mathrm{CH}_{3} \mathrm{Br}$ and $\mathrm{CH}_{2} \mathrm{Br}_{2}$ as simulated by CAM-Chem (dashed lines) for the last of a 10-yr run with a composite of aircraft observations (solid lines) in the tropical regions from the missions PEM-Tropics A (1996), PEM-Tropics B (1999) and TRACE-P (2001). Model results are averaged within the geographical region of each campaign considering latitudes between $30^{\circ} \mathrm{N}$ and $30^{\circ} \mathrm{S}$ and matching seasons. Shaded areas and horizontal bars represent the standard deviation of modelled fields and observations, respectively.

\subsection{Tropical tropospheric ozone}

Simulated vertical profiles of ozone are compared with Southern Hemisphere Additional Ozonesonde Network (SHADOZ; Thompson et al., 2003a, b) and World Ozone and Ultraviolet Radiation Data Centre (WOUDC, ftp://ftp.tor.ec. gc.ca/) ozone profiles at three marine locations (San Cristobal - Galapagos, Fiji, and Naha - Japan), where long-term measurements are available in the vicinity of the above mentioned airborne field measurement campaigns (Fig. 3). The tropical SHADOZ sites San Cristobal and Fiji are located within the regions covered by PEM-Tropics A and PEMTropics B, respectively, while Naha is a sub-tropical site sampled during Trace-P. The model reproduces well the observed magnitude and structure of ozone throughout the tropospheric column. Despite the underestimation of the measurements in the lower and mid-troposphere over Fiji, the modelled ozone mixing ratios are within the variability of the observations. Additionally, the multi-year seasonal variation of simulated ozone mixing ratios at the surface $(1000 \mathrm{hPa})$ and in the upper troposphere $(300 \mathrm{hPa})$ also agrees reasonably well with observations at the three sites (Fig. 4). A good match between model and surface observations is found for Naha while the model overestimates the ozone mixing ratios measured at San Cristobal and underestimates them at Fiji; note that in the case of the low ozone events the deviations between model and observations are magnified by the loga- rithmic scale used. No significant over- or underestimation is found for the model results at $300 \mathrm{hPa}$.

\subsection{Chemical ozone loss}

In the TMBL $\left(20^{\circ} \mathrm{S}-20^{\circ} \mathrm{N}\right)$, the annually integrated rate of surface ozone loss due to halogen chemistry is $\sim 6 \times$ $10^{5}$ molecule $\mathrm{cm}^{-3} \mathrm{~s}^{-1}\left(\sim 0.15 \mathrm{ppbv} \mathrm{h}^{-1}\right.$ at daytime) (Fig. 5, left). The integrated contribution of iodine-mediated reactions to the total rate of surface ozone loss is three times larger than that of bromine chemistry alone. When both chemistries are combined via the reaction of $\mathrm{IO}+\mathrm{BrO}$ to $\mathrm{Br}+\mathrm{OIO}(75 \%)$ and $\mathrm{Br}+\mathrm{I}(25 \%)$, the ozone loss rate is fourfold that of bromine chemistry alone. On an annual average basis, in the absence of halogens, the model sampled at Cape Verde predicts a diurnal loss of 2.5 ppbv by mid-afternoon (Fig. 5, right). However, in the presence of halogens the loss is $\sim 3.2 \mathrm{ppbv}$, shifting the timing of the minimum ozone level. This is in agreement with observed diurnal ozone loss and previous zero- and one-dimensional model analyses at this location (Read et al., 2008; Mahajan et al., 2010).

In the tropical troposphere the contribution to chemical ozone loss is dominated by ozone and $\mathrm{HO}_{\mathrm{x}}$ photochemistry (Fig. 6, middle and top panels). However, we find that the integrated loss due to halogen-catalysed ozone destruction cycles is $15-30 \%$ of the total ozone chemical loss throughout the tropospheric column (Fig. 6, bottom). Halogen-induced ozone loss is enhanced in the $400-150 \mathrm{hPa}$ pressure range. 


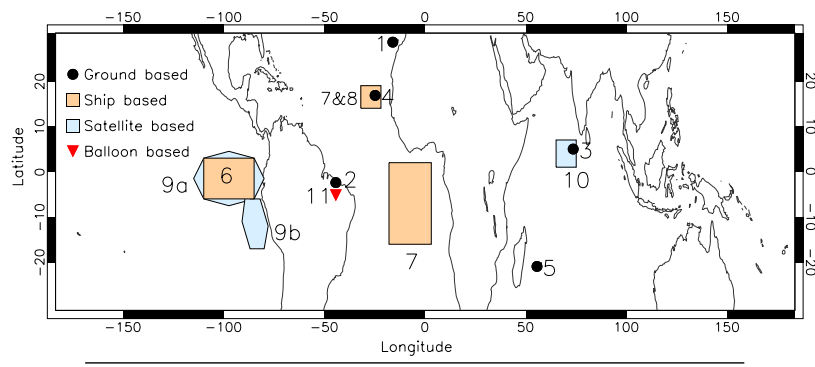

\begin{tabular}{lrr}
\hline \multirow{2}{*}{ No. (species) } & \multicolumn{2}{c}{ Daytime avg. mixing ratio (pptv) } \\
\cline { 2 - 3 } & Modelled & Observed \\
\hline \multicolumn{2}{l}{ Ground based measurements } \\
\hline 1 (IO) & 0.4 & 1.2 \\
$2(\mathrm{IO})$ & 0.7 & $<0.2-0.8$ \\
$3(\mathrm{IO})$ & 1.0 & $\sim 2.4$ \\
$4(\mathrm{IO}, \mathrm{BrO})$ & $1.0,2.0$ & $1.0,2.0$ \\
5 (BrO) & 0.8 & $<0.5$ \\
\hline
\end{tabular}

Ship based measurements

\begin{tabular}{lcc}
\hline $6(\mathrm{IO})$ & 1.0 & $\sim 3.5$ \\
$7(\mathrm{BrO})$ & 0.8 & $<3.6$ \\
$8(\mathrm{BrO})$ & 1.2 & $<3.0$ \\
\hline \multicolumn{2}{l}{ Satellite based measurements } & \\
\hline 9a $(\mathrm{IO})$ & 1.0 & $\sim 3.3$ \\
$9 \mathrm{~b}(\mathrm{IO})$ & 1.0 & $\sim 3.3$ \\
$10(\mathrm{IO})$ & 1.0 & $\sim 2.4$ \\
\hline Balloon based measurements & \\
\hline $11(\mathrm{IO})$ & 0.02 & $\sim 0.1$ \\
$11(\mathrm{BrO})$ & 0.5 & $\sim 1.0$ \\
\hline
\end{tabular}

Fig. 2. Mixing ratios of iodine oxide (IO) and bromine oxide (BrO) in the TMBL. Observations were compiled from ground-, ship-, satellite- and balloon-based platforms. Modelled mixing ratios simulated by CAM-Chem correspond to averages for the same areas and months as the observations. Daytime represents sunlit hours. Where indicated the mixing ratios are estimated from differential slant column densities (dSCD). 1: Allan et al. (2000); 2: Butz et al. (2009); 3: estimated from dSCD $=3.5 \times 10^{13}$ molecule $\mathrm{cm}^{-2}$ (Oetjen, 2009); 4: Read et al. (2008); 5: estimated from dSCD (Theys et al., 2007); 6: peak mixing ratio, estimated from dSCD

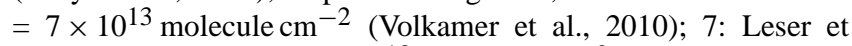
al. (2003); 8: dSCD $<1.2 \times 10^{13}$ molecule $\mathrm{cm}^{-2}$, observations from the upwelling region around Mauritania with values up to $10 \mathrm{pptv}$ are excluded for comparison with modelled data (Martin et al., 2009); 9: estimated from dSCDs $=8 \times 10^{12}$ molecule $\mathrm{cm}^{-2}$ considering an air mass factor (AMF) of 1 and a mixed layer of $1 \mathrm{~km}$ at the surface (Schönhardt et al., 2008); 10: as (9) but with dSCD = $6 \times 10^{12}$ molecule $\mathrm{cm}^{-2}$; 11: upper limit of IO (Butz et al., 2009) and $\mathrm{BrO}$ (Dorf et al., 2008) in the upper troposphere.

From a climate perspective, this finding is particularly relevant because the sensitivity of long-wave absorption by ozone is the largest in the upper troposphere (e.g. Lacis et

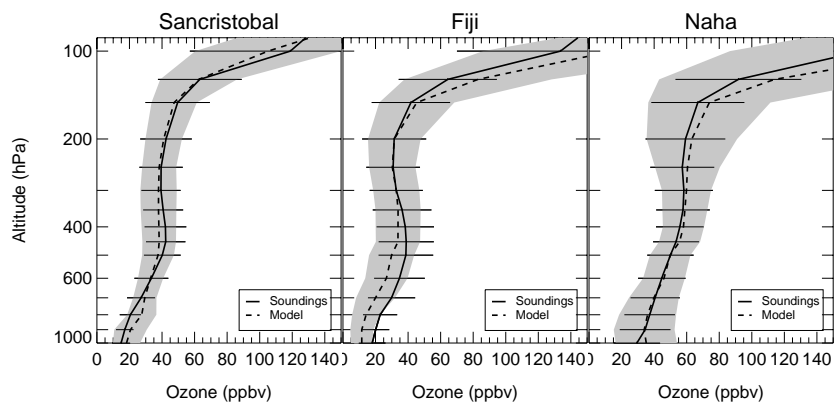

Fig. 3. Comparison of average vertical profiles for ozone as simulated by CAM-Chem for the last of a 10-yr run (dashed lines) with observations at three sites (San Cristobal, Galapagos, $1^{\circ} \mathrm{S}-89^{\circ} \mathrm{W}$; Fiji, $18^{\circ} \mathrm{S}-178^{\circ} \mathrm{E}$; Naha, Japan, $26^{\circ} \mathrm{N}-127^{\circ} \mathrm{E}$ ) of the SHADOZ and WOUDC ozonesonde networks (solid lines). Shaded areas and horizontal bars represent the standard deviation of modelled fields and observations, respectively.
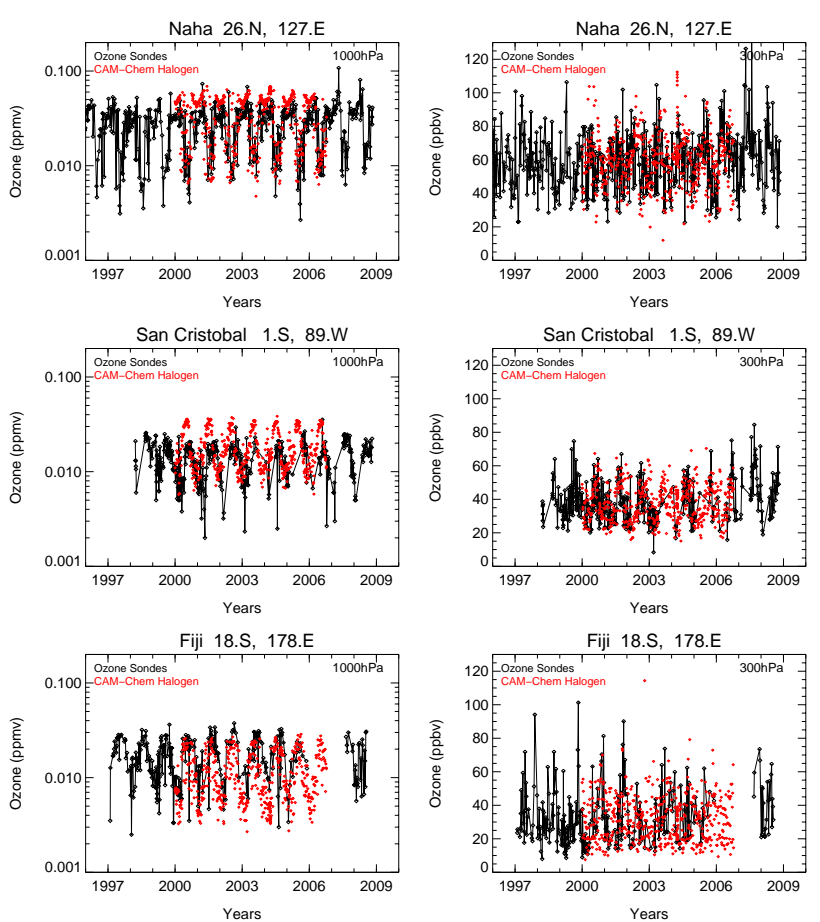

Fig. 4. Time series of observed and modelled ozone at (left) $1000 \mathrm{hPa}$ and (right) $300 \mathrm{hPa}$ for the location of three ozonesonde sites in the proximity of the tropics. A logarithmic vertical scale has been used for the $1000 \mathrm{hPa}$ time series to draw attention to the low ozone events. The time frequency is of around 30-40 observations per year and every 10 days for modelled ozone.

al., 1990; Kiehl et al., 1999; Worden et al., 2008). The halogen precursor source region and rapid vertical transport of air determine the contribution of halogen chemistry to ozone depletion and the extent of ozone-poor air in the tropical upper troposphere. Within deep convection zones, this can proceed via efficient uplift of: (i) air that has been ozone-depleted 


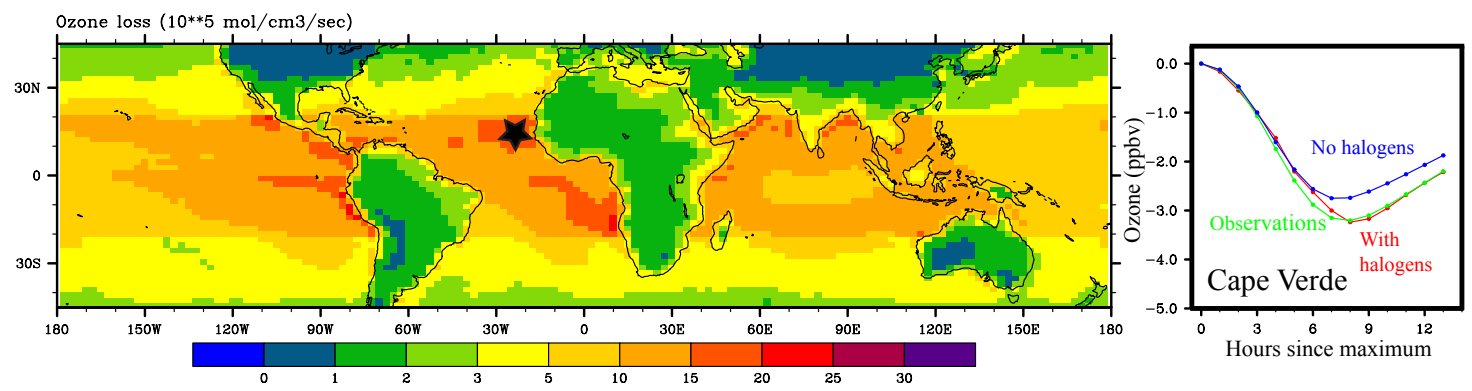

Fig. 5. (Left) Surface ozone loss (in $10^{5}$ molecule $\mathrm{cm}^{-3} \mathrm{~s}^{-1}$ ) resulting from including tropospheric halogen chemistry in CAM-Chem. (Right) Annual average of diurnal ozone loss observed and simulated by CAM-Chem (without and with tropospheric halogen chemistry) at Cape Verde.
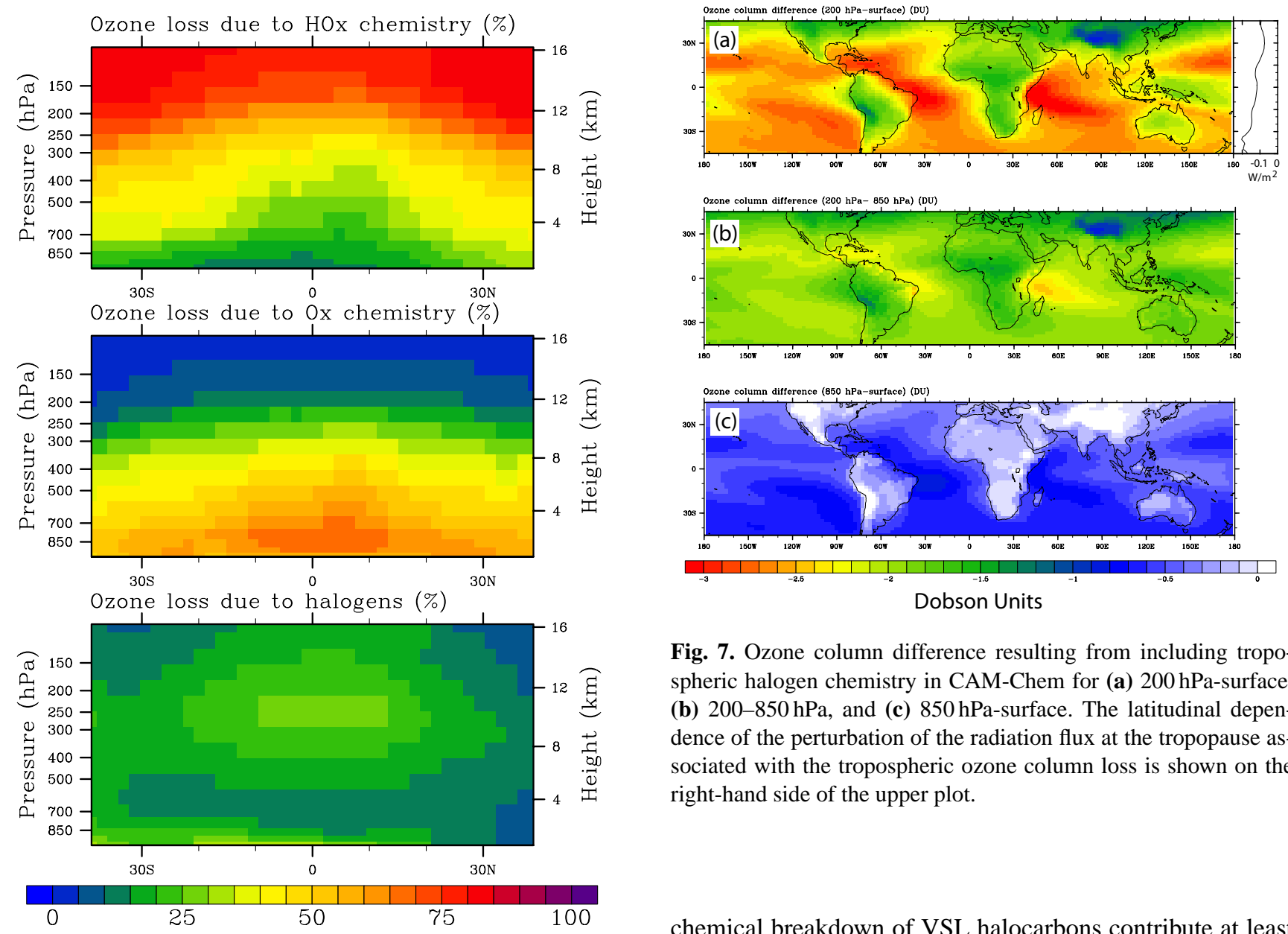

Dobson Units

Fig. 7. Ozone column difference resulting from including tropospheric halogen chemistry in CAM-Chem for (a) $200 \mathrm{hPa}$-surface, (b) $200-850 \mathrm{hPa}$, and (c) $850 \mathrm{hPa}$-surface. The latitudinal dependence of the perturbation of the radiation flux at the tropopause associated with the tropospheric ozone column loss is shown on the right-hand side of the upper plot.

Fig. 6. Percentage of the annually integrated chemical ozone loss from $\mathrm{HO}_{\mathrm{x}}, \mathrm{O}_{\mathrm{x}}$ and halogen photochemistry as simulated by CAMChem.

through chemical processing in the clean TMBL, and (ii) VSL organic iodine and bromine species whose breakdown in the upper troposphere initiates ozone depletion cycles. Our results indicate that vertical transport and efficient photo-

chemical breakdown of VSL halocarbons contribute at least to $80 \%$ of the halogen-driven ozone loss in the upper troposphere. The combination of these processes leads to an average reduction of 2.5 Dobson Units (DU), more than $10 \%$ of the tropospheric ozone column, over large regions of the tropics (Fig. 7, top). Most of the ozone loss (measured in DU) occurs in the mid- to upper-troposphere (pressure range between $850 \mathrm{hPa}$ and $200 \mathrm{hPa}$ ), above the TMBL (Fig. 7, middle). There is high regional variability, with the largest ozone loss found in the upper troposphere of the western tropical 
Pacific, Indian and Atlantic Oceans, within areas with efficient vertical transport.

The impact of halogen chemistry on tropical tropospheric ozone as simulated by CAM-Chem has been compared to results from previous three-dimensional global modelling studies that only considered bromine sources. To reflect the main sources of inorganic bromine in the tropics, von Glasow et al. (2004) used a generic organic bromine compound (with fixed mixing ratio of $30 \mathrm{pptv}$ ) that was broken down into $\mathrm{Br}$ by reaction with $\mathrm{OH}$, and also included a simplified parameterisation for the heterogeneous recycling of bromine on aerosols. They computed a zonally and annually averaged tropical tropospheric ozone loss due to bromine chemistry of 12-18\%. Yang et al. (2005) used VSL bromocarbon sources from Warwick et al. (2006), with a global Br flux that only deviates $15 \%$ from that used here (Ordóñez et al., 2012), and two different sea-salt formulations. They found an ozone reduction due to bromine chemistry of 4-6\% throughout most of the tropical troposphere, with maximum losses of around $8 \%$ for the southern tropics. The tropical tropospheric ozone loss due to bromine and iodine chemistry in CAM-Chem is of around 6-20\%, considerably larger than that calculated by Yang et al. (2005). This result was expected considering the much larger ozone depletion rate resulting from bromine and iodine chemistry, compared with bromine alone (Gilles et al., 1997; Saiz-Lopez et al., 2007; Read et al., 2008). The closer resemblance between the overall ozone loss calculated by our analysis and von Glasow et al. (2004) might be due to the different bromine loadings in the models. The $30 \mathrm{pptv} \mathrm{Br}$ from a generic organic source in von Glasow et al. (2004), compared to $\sim 13 \mathrm{pptv} \mathrm{Br}$ in the tropical troposphere within CAM-Chem ( $\sim 4$ pptv from VSL halocarbons and $\sim 9$ pptv from $\mathrm{CH}_{3} \mathrm{Br}$ ), might compensate for the lack of iodine sources in their study. However a direct comparison with their results is not possible since there is no information on the rate coefficient for the reaction of their generic source with $\mathrm{OH}$. Some deviations might also arise from the different treatment of heterogenous recycling in the three models.

\section{Radiative impact of halogen-driven ozone loss}

The climate significance of halogen-mediated ozone loss in the troposphere can be determined by the tropical annually integrated radiative impact from the tropospheric ozone depletion associated with the atmospheric processing of natural oceanic halogen sources. The radiative impact of halogen chemistry in the troposphere is computed using the CAMRT radiative transfer scheme (Collins et al., 2006). For that purpose, we calculate the radiative fluxes (shortwave and longwave, all sky) at the tropopause, after stratospheric temperature adjustment (Forster et al., 2007). These fluxes are computed using identical present-day environmental conditions (temperature, humidity, clouds, aerosols and surface albedo), except for tropospheric ozone, which is set to its distribution
Table 1. Annual average difference in the longwave and net (longwave plus shortwave) fluxes at the tropical tropopause $\left(20^{\circ} \mathrm{S}-\right.$ $20^{\circ} \mathrm{N}$ ) for two CAM-Chem simulations with and without VSL halogen sources.

\begin{tabular}{lcc}
\hline & Longwave flux $\left(\mathrm{W} \mathrm{m}^{-2}\right)$ & Net flux $\left(\mathrm{W} \mathrm{m}^{-2}\right)$ \\
\hline All-sky & -0.104 & -0.103 \\
Clear-sky & -0.138 & -0.122 \\
\hline
\end{tabular}

from the simulations with and without halogen chemistry. On an annual basis, the tropical difference (halogen minus no halogen) between those fluxes is $\approx-0.1 \mathrm{~W} \mathrm{~m}^{-2}$, defining the size of the contribution of the effect of tropospheric halogen chemistry on ozone alone to the radiative balance of the atmosphere. This estimate is quite reasonable considering that our tropical tropospheric ozone column is estimated to decrease by about $2.5 \mathrm{DU}$, leading to a $0.1 \mathrm{~W} \mathrm{~m}^{-2}$ imbalance when scaled by the $0.042 \mathrm{~W} \mathrm{~m}^{-2} \mathrm{DU}^{-1}$ estimated for all-sky conditions in Ramaswamy et al. (2001). The difference in the longwave fluxes from both simulations $(-0.138$ and $-0.104 \mathrm{~W} \mathrm{~m}^{-2}$ under clear-sky and all-sky conditions, respectively; see Table 1) can also be compared with recent satellite estimates of the longwave radiative effect (LWRE) of tropospheric ozone, i.e. the reduction in outgoing longwave radiation (OLR) at the top of the atmosphere (TOA) due to tropospheric ozone. This enables us to put into a broader context the significance of the radiative effect associated with the destruction of tropospheric ozone by VSL halogens over the tropics. Worden et al. (2008) estimated the LWRE of tropospheric ozone to be $0.48 \mathrm{~W} \mathrm{~m}^{-2}$ by using clear-sky ocean observations of the TES sensor in the upper troposphere (200-500 $\mathrm{hPa}$ ) for $45^{\circ} \mathrm{S}-45^{\circ} \mathrm{N}$ during the year 2006. Worden et al. (2011) developed a new approach to improve the accuracy of their LWRE estimate during August 2006. Interferences with water vapour were removed, which yields lower estimates of the OLR sensitivity to ozone, and results were computed for all observations over the full troposphere. They obtained a global average LWRE from tropospheric ozone of $0.50 \mathrm{~W} \mathrm{~m}^{-2}$ under clear-sky conditions and $0.33 \mathrm{~W} \mathrm{~m}^{-2}$ under all-sky conditions. This suggests that the negative contribution of halogen-driven ozone loss to the longwave radiative flux at the tropical tropopause is significant since it is around $30 \%$ of the positive contribution to the TOA radiation flux associated with infrared ozone absorption. Note, however, that our results are not directly comparable to the previous satellite estimates because the latter (i) exclude the stratospheric temperature adjustment and therefore represent instantaneous radiative forcings and (ii) are extended to areas outside the tropics. 


\section{Concluding remarks}

According to the IPCC Fourth Assessment Report (AR4) chapter 2 (Forster et al., 2007), the global estimate of the direct RF resulting from the increase in tropospheric ozone since 1750 (on average $+0.35 \mathrm{~W} \mathrm{~m}^{-2}$ ) has a medium level of scientific understanding which originates from the uncertainties in the model formulations used and the inability of the models to reproduce the low ozone concentrations indicated by the very uncertain semi-quantitative observations during the late 19th century (see e.g. Volz and Kley, 1988; Marenco et al., 1994; Pavelin et al., 1999; Mickley et al., 2001; Shindell et al., 2003; Lamarque et al., 2005). This study shows that accounting for oceanic halogen sources and their chemistry the natural rate of chemical ozone removal in the tropical marine troposphere is up to $\sim 30 \%$ larger than previously assumed in global chemistry-climate models, and that the associated contribution to the TOA radiation flux is of similar magnitude (i.e. about $30 \%$ ) as the long-wave absorption by tropospheric ozone. The inclusion of this natural component of the ozone budget has the potential to improve simulations of preindustrial ozone baseline levels, and therefore estimates of anthropogenically-influenced increase in tropospheric ozone concentrations and its associated RF. Note that reactive bromine and iodine not only deplete $\mathrm{O}_{3}$ through efficient catalytic cycles but are also coupled with $\mathrm{HO}_{\mathrm{x}}$ and $\mathrm{NO}_{\mathrm{x}}$ chemistry. Even though halogens have been present since preindustrial times, they may have altered ozone concentrations in a different way under changing $\mathrm{NO}_{\mathrm{x}}$ regimes. Finally, fluxes of natural halogenated VSL species from the ocean surface are controlled by biological, physical and photochemical mechanisms that may respond to future changes in climate processes (WMO, 2011). Therefore, further field and laboratory work is needed to assess how climate variability may influence ocean-atmosphere exchange of reactive halogen precursors and its associated impact on the radiation balance in the tropical marine troposphere.

Acknowledgements. The authors are grateful to S. Solomon for valuable discussions and comments on this manuscript. We thank the University of York for making available the ozone data at the Cape Verde Atmospheric Observatory. Ozonesonde data at Naha were obtained from the World Ozone and Ultraviolet Radiation Data Centre (WOUDC) operated by Environment Canada, Toronto, Ontario, Canada under the auspices of the World Meteorological Organization. This work was supported by the Department of Energy under the SciDAC program. The CESM project is supported by the National Science Foundation and the Office of Science (BER) of the US Department of Energy. The National Center for Atmospheric Research is operated by the University Corporation for Atmospheric Research under sponsorship of the National Science Foundation.

Edited by: M. Van Roozendael

\section{References}

Allan, B. J., McFiggans, G., Plane, J. M. C., and Coe, H.: Observations of iodine monoxide in the remote marine boundary layer, $\mathrm{J}$. Geophys. Res., 105, 14363-14369, 2000.

Bell, N., Hsu, L., Jacob, D. J., Schultz, M. G., Blake, D. R., Butler, J. H., King, D. B., Lobert, J. M., and Maier-Reimer, E.: Methyl iodide: Atmospheric budget and use as a tracer of marine convection in global models, J. Geophys. Res., 107, 4340, doi:10.1029/2001JD001151, 2002.

Bremaud, P. J., Taupin, F., Thompson, A. M., and Chaumerliac, N.: Ozone nighttime recovery in the marine boundary layer: Measurement and simulation of the ozone diurnal cycle at Reunion Island, J. Geophys. Res., 103, 3463-3473, doi:10.1029/97JD01972, 1998.

Burkert, J., Andrés-Hernández, M. D., Reichert, L., Meyer-Arnek, J., Doddridge, B., Dickerson, R. R., Mühle, J., Zahn, A., Carsey, T., and Burrows, J. P.: Trace gas and radical diurnal behavior in the marine boundary layer during INDOEX 1999, J. Geophys. Res., 108, 8000, doi:10.1029/2002JD002790, 2003.

Butz, A., Bösch, H., Camy-Peyret, C., Chipperfield, M. P., Dorf, M., Kreycy, S., Kritten, L., Prados-Román, C., Schwärzle, J., and Pfeilsticker, K.: Constraints on inorganic gaseous iodine in the tropical upper troposphere and stratosphere inferred from balloon-borne solar occultation observations, Atmos. Chem. Phys., 9, 7229-7242, doi:10.5194/acp-9-7229-2009, 2009.

Collins, W. D., Rasch, P. J., Boville, B. A., Hack, J. J., McCaa, J. R., Williamson, D. L., Briegleb, B. P., Bitz, C. M., Lin, S.-J., and Zhang, M.: The formulation and atmospheric Simulation of the Community Atmosphere Model Version 3 (CAM3), J. Climate, 19, 2144-2161, 2006.

de Laat, A. T. J., Zachariasse, M., Roelofs, G. J., van Velthoven, P., Dickerson, R. R., Rhoads, K. P., Oltmans, S. J., and Lelieveld, J.: Tropospheric $\mathrm{O}_{3}$ distribution over the Indian Ocean during spring 1995 evaluated with a chemistry-climate model, J. Geophys. Res., 104, 13881-13893, 1999.

Dickerson, R. R., Rhoads, K. P., Carsey, T. C., Oltmans, S. J., Burrows, J. P., and Crutzen, P. J.: Ozone in the remote marine boundary layer: A possible role for halogens, J. Geophys. Res., 104, 21385-21395, doi:10.1029/1999JD900023, 1999.

Dorf, M., Butz, A., Camy-Peyret, C., Chipperfield, M. P., Kritten, L., and Pfeilsticker, K.: Bromine in the tropical troposphere and stratosphere as derived from balloon-borne $\mathrm{BrO}$ observations, Atmos. Chem. Phys., 8, 7265-7271, doi:10.5194/acp-8-72652008, 2008.

Emmons, L. K., Walters, S., Hess, P. G., Lamarque, J.-F., Pfister, G. G., Fillmore, D., Granier, C., Guenther, A., Kinnison, D., Laepple, T., Orlando, J., Tie, X., Tyndall, G., Wiedinmyer, C., Baughcum, S. L., and Kloster, S.: Description and evaluation of the Model for Ozone and Related chemical Tracers, version 4 (MOZART-4), Geosci. Model Dev., 3, 43-67, doi:10.5194/gmd3-43-2010, 2010.

Forster, P., Ramaswamy, V., Artaxo, P., Berntsen, T., Betts, R., Fahey, D.W., Haywood, J., Lean, J., Lowe, D. C., Myhre, G., Nganga, J., Prinn, R., Raga, G., Schulz, M., and Van Dorland, R.: Changes in Atmospheric Constituents and in Radiative Forcing, in Climate Change 2007: The Physical Science Basis, Contribution of Working Group I to the Fourth Assessment Report of the Intergovernmental Panel on Climate Change, edited by: Solomon, S., Qin, D., Manning, M., Chen, Z., Marquis, M., Av- 
eryt, K. B., Tignor, M., and Miller, H. L., Cambridge University Press, Cambridge, United Kingdom and New York, NY, USA, 129-234, 2007.

Garland, J. A. and Curtis, H.: Emission of Iodine From the Sea Surface in the Presence of Ozone. J. Geophys. Res. Oc., 86, 31833186, 1981.

Gent, P. R., Yeager, S. G., Neale, R. B., Levis, S., and Bailey, D. A.: Improvements in a half degree atmosphere/land version of the CCSM, Clim. Dynam., 34, 819-833, doi:10.1007/s00382-0090614-8, 2010.

Gilles, M. K., Turnipseed, A. A., Burkholder, J. B., Ravishankara, A. R., and Solomon, S.: Kinetics of the IO Radical. 2. Reaction of IO with BrO, J. Phys. Chem. A, 101, 5526-5534, 1997.

Hense, I. and Quack, B.: Modelling the vertical distribution of bromoform in the upper water column of the tropical Atlantic Ocean, Biogeosciences, 6, 535-544, doi:10.5194/bg-6-535-2009, 2009.

Hoell, J. M., Davis, D. D., Jacob, D. J., Rodgers, M. O., Newell, R. E., Fuelberg, H. E., McNeal, R. J., Raper, J. L., and Bendura, R. J.: Pacific Exploratory Mission in the tropical Pacific: PEM-Tropics A, August-September 1996, J. Geophys. Res., 104, 5567-5583, 1999.

Horowitz, L. W., Walters, S., Mauzerall, D. L., Emmons, L. K., Rasch, P. J., Granier, C., Tie, X., Lamarque, J.-F., Schultz, M. G., Tyndall, G. S., Orlando, J. J., and Brasseur, G. P.: A global simulation of tropospheric ozone and related tracers: Description and evaluation of MOZART version 2, J. Geophys. Res., 108, 4784, doi:10.1029/2002JD002853, 2003.

Jacob, D. J., Crawford, J. H., Kleb, M. M., Connors, V. S., Bendura, R. J., Raper, J. L., Sachse, G. W., Gille, J. C., Emmons, L., and Heald, C. L: Transport and Chemical Evolution over the Pacific (TRACE-P) aircraft mission: Design, execution, and first results, J. Geophys. Res., 108, 9000, doi:10.1029/2002JD003276, 2003.

Johnson, J. E., Gammon, R. H., Larsen, J., Bates, T. S., Oltmans, S. J., and Farmer, J. C.: Ozone in the Marine Boundary Layer Over the Pacific and Indian Oceans: Latitudinal Gradients and Diurnal Cycles, J. Geophys. Res., 95, 11847-11856, 1990.

Jones, C. E., Hornsby, K. E., Sommariva, R., Dunk, R. M., von Glasow, R., McFiggans, G., and Carpenter, L. J.: Quantifying the contribution of marine organic gases to atmospheric iodine, Geophys. Res. Lett., 37, L18804, doi:10.1029/2010GL043990, 2010.

Kiehl, J. T., Schneider, T. L., Portmann, R. W., and Solomon, S.: Climate forcing due to tropospheric and stratospheric ozone, J. Geophys. Res., 104, 31239-31254, 1999.

Kinnison, D. E., Brasseur, G. P., Walters, S., Garcia, R. R., Marsh, D. R., and Sassi, F., Harvey, V. L., Randall, C. E., Emmons, L., Lamarque, J. F., Hess, P., Orlando, J. J., Tie, X. X., Randel, W., Pan, L. L., Gettelman, A., Granier, C., Diehl, T., Niemeier, U., and Simmons, A. J.: Sensitivity of chemical tracers to meteorological parameters in the MOZART-3 chemical transport model, J. Geophys. Res. 112, D20302, doi:10.1029/2006JD007879, 2007.

Kley, D., Crutzen, P. J., Smit, H. G. J., Vömel, H., Oltmans, S. J., Grassl, H., and Ramanathan, V: Observations of Near-Zero Ozone Concentrations Over the Convective Pacific: Effects on Air Chemistry, Science, 274, 230-233, 1996.

Lacis, A. A., Wuebbles, D. J., and Logan, J. A.: Radiative Forcing of Climate by Changes in the Vertical Distribution of Ozone, J. Geophys. Res., 95, 9971-9981, 1990.
Lamarque, J.-F. and Solomon, S.: Impact of Changes in Climate and Halocarbons on Recent Lower Stratosphere Ozone and Temperature Trends, J. Climate, 23, 2599-2611, 2010.

Lamarque, J.-F., Hess, P., Emmons, L., Buja, L., Washington, W., and Granier, C.: Tropospheric ozone evolution between 1890 and 1990, J. Geophys. Res., 110, D08304, doi:10.1029/2004JD005537, 2005.

Lamarque, J.-F., Bond, T. C., Eyring, V., Granier, C., Heil, A., Klimont, Z., Lee, D., Liousse, C., Mieville, A., Owen, B., Schultz, M. G., Shindell, D., Smith, S. J., Stehfest, E., Van Aardenne, J., Cooper, O. R., Kainuma, M., Mahowald, N., McConnell, J. R., Naik, V., Riahi, K., and van Vuuren, D. P.: Historical (1850-2000) gridded anthropogenic and biomass burning emissions of reactive gases and aerosols: methodology and application, Atmos. Chem. Phys., 10, 7017-7039, doi:10.5194/acp10-7017-2010, 2010.

Lamarque, J.-F., Emmons, L. K., Hess, P. G., Kinnison, D. E., Tilmes, S., Vitt, F., Heald, C. L., Holland, E. A., Lauritzen, P. H., Neu, J., Orlando, J. J., Rasch, P. J., and Tyndall, G. K.: CAM-chem: description and evaluation of interactive atmospheric chemistry in the Community Earth System Model, Geosci. Model Dev., 5, 369-411, doi:10.5194/gmd-5-369-2012, 2012.

Leser, H., Hönninger, G., and Platt, U.: MAX-DOAS measurements of $\mathrm{BrO}$ and $\mathrm{NO}_{2}$ in the marine boundary layer, Geophys. Res. Lett., 30, 1537, doi:10.1029/2002GL015811, 2003.

Mahajan, A. S., Plane, J. M. C., Oetjen, H., Mendes, L., Saunders, R. W., Saiz-Lopez, A., Jones, C. E., Carpenter, L. J., and McFiggans, G. B.: Measurement and modelling of tropospheric reactive halogen species over the tropical Atlantic Ocean, Atmos. Chem. Phys., 10, 4611-4624, doi:10.5194/acp-10-4611-2010, 2010.

Marenco, A., Gouget, H., Nédélec, P., Pages, J.-P., and Karcher, F.: Evidence of a long-term increase in tropospheric ozone from Pic du Midi data series: Consequences: Positive radiative forcing, J. Geophys. Res., 99, 16617-16632, 1994.

Martin, M., Pöhler, D., Seitz, K., Sinreich, R., and Platt, U.: BrO measurements over the Eastern North-Atlantic, Atmos. Chem. Phys., 9, 9545-9554, doi:10.5194/acp-9-9545-2009, 2009.

McFiggans, G., Plane, J. M. C., Allan, B. J., Carpenter, L. J., Coe, H., and O'Dowd, C.: A modeling study of iodine chemistry in the marine boundary layer, J. Geophys. Res., 105, 14371-14385, 2000.

Mickley, L. J., Jacob, D. J., and Rind, D.: Uncertainty in preindustrial abundance of tropospheric ozone: Implications for radiative forcing calculations, J. Geophys. Res., 106, 3389-3399, 2001.

Nagao, I., Matsumoto, K., and Tanaka, H.: Sunrise ozone destruction found in the sub-tropical marine boundary layer, Geophys. Res. Lett., 26, 3377-3380, 1999.

Oetjen, H.: Measurement of halogen oxides by scattered sunlight differential optical absorption spectroscopy, $\mathrm{PhD}$ thesis, University of Bremen, Germany, 2009.

Oltmans, S. J. and Levy II, H.: Seasonal cycle of surface ozone over the western North Atlantic, Nature, 358, 392-394, 1992.

Ordóñez, C., Lamarque, J.-F., Tilmes, S., Kinnison, D. E., Atlas, E. L., Blake, D. R., Sousa Santos, G., Brasseur, G., and Saiz-Lopez, A.: Bromine and iodine chemistry in a global chemistry-climate model: description and evaluation of very short-lived oceanic sources, Atmos. Chem. Phys., 12, 1423-1447, doi:10.5194/acp12-1423-2012, 2012. 
Pavelin, E. G., Johnson, C. E., Rughooputh, S., and Toumi, R.: Evaluation of pre-industrial surface ozone measurements made using Schönbein's method, Atmos. Environ., 33, 919-929, 1999.

Ramaswamy, V., Boucher, O., Haigh, J., Hauglustaine, D., Haywood, J., Myhre, G., Nakajima, T., Shi, G. Y., and Solomon, S.: Radiative Forcing of Climate Change, in Climate Change 2001: The Scientific Basis, Contribution of Working Group I to the Third Assessment Report of the Intergovernmental Panel on Climate Change, edited by: Houghton, J. T., Ding, Y., Griggs, D. J., Noguer, M., van der Linden, P. J., Dai, X., Maskell, K., and Johnson, C. A., Cambridge University Press, Cambridge, United Kingdom and New York, NY, USA, 349-416, 2001.

Raper, J. L., Kleb, M. M., Jacob, D. J., Davis, D. D., Newell, R. E., Fuelberg, H. E., Bendura, R. J., Hoell, J. M., and Mc-Neal, R. J.: Pacific Exploratory Mission in the Tropical Pacific: PEMTropics B, March-April 1999, J. Geophys. Res., 106, 3240132425, 2001.

Rayner, N. A., Parker, D. E., Horton, E. B., Folland, C. K., Alexander, L. V., Rowell, D. P., Kent, E. C., and Kaplan, A.: Global analyses of sea surface temperature, sea ice, and night marine air temperature since the late nineteenth century, J. Geophys. Res., 108, 4407, doi:10.1029/2002JD002670, 2003.

Read, K. A., Mahajan, A. S., Carpenter, L. J., Evans, M. J., Faria, B. V. E., Heard, D. E., Hopkins, J. R., Lee, J. D., Moller, S. J., Lewis, A. C., Mendes, L., McQuaid, J. B., Oetjen, H., Saiz-Lopez, A., Pilling, M. J., and Plane, J. M. C.: Extensive halogen-mediated ozone destruction over the tropical Atlantic Ocean, Nature, 453, 1232-1235, 2008.

Reeser, D. I., Jammoul, A., Clifford, D., Brigante, M., D’Anna, B., George, C., and Donaldson, D. J.: Photoenhanced Reaction of Ozone with Chlorophyll at the Seawater Surface, J. Phys. Chem. C, 113, 2071-2077, 2009.

Saiz-Lopez, A. and Plane, J. M. C.: Novel iodine chemistry in the marine boundary layer, Geophys. Res. Lett., 31, L04112, doi:10.1029/2003GL019215, 2004.

Saiz-Lopez, A., Mahajan, A. S., Salmon, R. A., Bauguitte, S. J.-B, Jones, A. E., Roscoe, H. K., and Plane, J. M. C.: Boundary Layer Halogens in Coastal Antarctica, Science, 317, 348-351, 2007.

Saiz-Lopez, A., Plane, J. M. C., Mahajan, A. S., Anderson, P. S., Bauguitte, S. J.-B., Jones, A. E., Roscoe, H. K., Salmon, R. A., Bloss, W. J., Lee, J. D., and Heard, D. E.: On the vertical distribution of boundary layer halogens over coastal Antarctica: implications for $\mathrm{O}_{3}, \mathrm{HO}_{\mathrm{x}}, \mathrm{NO}_{\mathrm{x}}$ and the $\mathrm{Hg}$ lifetime, Atmos. Chem. Phys., 8, 887-900, doi:10.5194/acp-8-887-2008, 2008.

Sakamoto, Y., Yabushita, A., Kawasaki, M., and Enami, S.: Direct Emission of $\mathrm{I}_{2}$ Molecule and IO Radical from the Heterogeneous Reactions of Gaseous Ozone with Aqueous Potassium Iodide Solution, J. Phys. Chem., A 113, 7707-7713, 2009.

Schönhardt, A., Richter, A., Wittrock, F., Kirk, H., Oetjen, H., Roscoe, H. K., and Burrows, J. P.: Observations of iodine monoxide columns from satellite, Atmos. Chem. Phys., 8, 637-653, doi:10.5194/acp-8-637-2008, 2008.

Shindell, D. T., Faluvegi, G., and Bell, N.: Preindustrial-to-presentday radiative forcing by tropospheric ozone from improved simulations with the GISS chemistry-climate GCM, Atmos. Chem. Phys., 3, 1675-1702, doi:10.5194/acp-3-1675-2003, 2003.

Shiotani, M., Fujiwara, M., Hasebe, F., Hashizume, H., Vömel, H., Oltmans, S. J., and Watanabe, T.: Ozonesonde Observations in the Equatorial Eastern Pacific - the Shoyo-Maru Survey, J. Met.
Soc. Japan, 80, 897-909, 2002.

Solomon, S., Thompson, D. W. J., Portmann, R. W., Oltmans, S. J., and Thompson, A. M.: On the distribution and variability of ozone in the tropical upper troposphere: Implications for tropical deep convection and chemical-dynamical coupling, Geophys. Res. Lett., 32, L23813, doi:10.1029/2005GL024323, 2005.

Sousa Santos, G.: The Effect of Halogens on Global Tropospheric Ozone, PhD Thesis, Max Planck Institute for Meteorology, Hamburg, Germany, 2008.

Takashima, H. Shiotani, M., Fujiwara, M., Nishi, N., and Hasebe, F.: Ozonesonde observations at Christmas Island $\left(2^{\circ} \mathrm{N}, 157^{\circ} \mathrm{W}\right)$ in the equatorial central Pacific, J. Geophys. Res., 113, D10112, doi:10.1029/2007JD009374, 2008.

Theys, N., Van Roozendael, M., Hendrick, F., Fayt, C., Hermans, C., Baray, J.-L., Goutail, F., Pommereau, J.-P., and De Mazière, M.: Retrieval of stratospheric and tropospheric BrO columns from multi-axis DOAS measurements at Reunion Island $\left(21^{\circ} \mathrm{S}\right.$, $56^{\circ}$ E), Atmos. Chem. Phys., 7, 4733-4749, doi:10.5194/acp-74733-2007, 2007.

Thompson, A. M., Witte, J. C., McPeters, R. D., Oltmans, S. J., Schmidlin, F. J., Logan, J. A., Fujiwara, M., Kirchhoff, V. W. J. H., Posny, F., Coetzee, G. J. R., Hoegger, B., Kawakami, S., Ogawa, T., Johnson, B. J., Vömel, H., and Labow, G.: Southern Hemisphere Additional Ozonesondes (SHADOZ) 1998-2000 tropical ozone climatology 1. Comparison with Total Ozone Mapping Spectrometer (TOMS) and ground-based measurements, J. Geophys. Res., 108, 8238, doi:10.1029/2001JD000967, 2003a.

Thompson, A. M., Witte, J. C., Oltmans, S. J., Schmidlin, F. J., Logan, J. A., Fujiwara, M., Kirchhoff, V. W. J. H., Posny, F., Coetzee, G. J. R., Hoegger, B., Kawakami, S., Ogawa, T., Fortuin, J. P. F., and Kelder, H. M.: Southern Hemisphere Additional Ozonesondes (SHADOZ) 1998-2000 tropical ozone climatology 2. Tropospheric variability and the zonal wave-one, J. Geophys. Res., 108, 8241, doi:10.1029/2002JD002241, 2003b.

Volkamer, R., Coburn, S. C., Dix, B. K., and Sinreich, R.: The Eastern Pacific Ocean is a source for short lived atmospheric gases: Glyoxal and Iodine Oxide, Newsletter of the Climate Variability and Predictability Programme (CLIVAR), 15, 30-33, 2010.

Volz, A. and Kley, D.: Evaluation of the Montsouris series of ozone measurements made in the nineteenth century, Nature, 332, 240242, 1988.

Vömel, H. and Diaz, K.: Ozone sonde cell current measurements and implications for observations of near-zero ozone concentrations in the tropical upper troposphere, Atmos. Meas. Tech., 3, 495-505, doi:10.5194/amt-3-495-2010, 2010.

von Glasow, R., von Kuhlmann, R., Lawrence, M. G., Platt, U., and Crutzen, P. J.: Impact of reactive bromine chemistry in the troposphere, Atmos. Chem. Phys., 4, 2481-2497, doi:10.5194/acp-42481-2004, 2004.

Warwick, N. J., Pyle, J. A., Carver, G. D., Yang, X., Savage, N. H., O'Connor, F. M., and Cox, R. A.: Global modelling of biogenic bromocarbons, J. Geophys. Res., 111, D24305, doi:10.1029/2006JD007264, 2006.

Worden, H. M., Bowman, K. W., Worden, J. R., Eldering, A., and Beer, R.: Satellite measurements of the clear-sky greenhouse effect from tropospheric ozone, Nature Geosci., 1, 305-308, 2008.

Worden, H. M., Bowman, K. W., Kulawik, S. S., and Aghedo, A. M.: Sensitivity of outgoing longwave radiative flux to the global 
vertical distribution of ozone characterized by instantaneous radiative kernels from Aura-TES, J. Geophys. Res., 116, D14115, doi:10.1029/2010JD015101, 2011.

World Meteorological Organization (WMO): Scientific Assessment of Ozone Depletion: 2010, Global Ozone Research and Monitoring Project - Report No. 52, 516 pp., Geneva, Switzerland, 2011.
Yang, X., Cox, R. A., Warwick, N. J., Pyle, J. A., Carver, G. D., O'Connor, F. M., and Savage, N. H.: Tropospheric bromine chemistry and its impacts on ozone: A model study, J. Geophys. Res., 110, D23311, doi:10.1029/2005JD006244, 2005. 